\title{
Risk Management of Islamic Banking: An Islamic Perspective
}

\author{
K. M. Anwarul Islam ${ }^{1}$ \\ Orobah Ali Barghouthi ${ }^{2}$ \\ ${ }^{1}$ Department of Business Administration, The Millennium University, Dhaka, Bangladesh \\ ${ }^{2}$ Faculty of Business and Economics, Department of Banking \& Finance, Alquds University, Abu Dis, Palestine. \\ Correspondence: Faculty of Business and Economics, Department of Banking \& Finance, Alquds \\ University,Abu Dis, Palestine, E-mail: obargothi@ hotmail.com
}

Received: November 20, $2017 \quad$ Accepted: November 25, $2017 \quad$ Online Published: November 30, 2017

\begin{abstract}
A large range of institutions, such as investment and commercial banks, investment firms and mutual insurance companies, are increasingly becoming part of the Islamic financial services market. Special attention is required for efficient risk management in Islamic banks. Nevertheless, it has several drawbacks that are necessary to understand properly. Risk management is about the pay-off mentality and the strategies and threats associated with it when dealing with them in relation to modern banking. Risk management is about classifying and identifying bank practices, processes and threats to control, track and measure them as an operational concern in banks. Islamic banks face considerable difficulties in identifying and managing risks compared to traditional banks due to greater challenges arising from the concept of profit loss sharing and the presence of unique risks in Islamic financing. This study explores in detail the need for risk management in Islamic banks (Ilias, S. E. B. 2012).
\end{abstract}

Keywords: Islamic Banking, Risk Management, Islamic Sharia.

\section{Introduction}

The fact that deposits in Islamic banks are not treated as a liability on the balance sheet does not mean that they should not have a minimum capital requirement and improved corporate governance as Emphasis on improved corporate governance and having minimum capital requirement go hand in hand with the need for improvements in risk management standards. Sound risk management practices will minimize adverse consequences faced by financial institutions during periods of uncertainty. Robust internal controls to provide qualitative standards are also necessary to complement the quantitative analysis of risk to provide a check and balance in the overall risk management practices.

An effective risk management system is central to supervisory efforts. The risk management system in Islamic institutions need to be able to address the unique characteristics and attributes associated with Islamic financing operations involving financial contracts and instruments which may give rise to other risks besides credit risk. The risk management infrastructure needs to be in place to facilitate the identification, measurement, monitoring and control of all inherent risks present in all the various types of financing so that the specific risks involved 
may be 'unbundled'. The complexities of the respective risks in the Islamic financial instruments therefore need to be fully explored and quantified to provide for their effective assessment and management.

\section{Data Analysis and Interpretation}

In the area of Islamic banking, the requirement to manage the risks becomes more important because of the unique peculiarities in the contracts. Basel II has, to a certain extent, incorporated some aspects in the identification of risks, in particular the credit, market and operational risks that can be assimilated by the Islamic banks in terms of its product offering. However, further refinement will have to be done by the Islamic financial specialists to assess the appropriateness of the capital definition in particular as outlined by the Basel committee. One of the considerations that need to be addressed in assessing the risks associated with the Islamic bank is with regard to the capital charge on its investment accounts. Basel II does not address this unique feature in its framework. Assets that are funded by monies in the investment account may not require the capital charge for the purpose of capital adequacy measurement except in the case of misconduct and negligence. Similarly, if the Islamic banking institutions were to be more engaged in the profit-sharing arrangement in its balance-sheets, it will require the Islamic bank to have a more rigorous risk management assessment and monitoring mechanism. This is an area that is being addressed by the Islamic Financial Services Board in the drafting of the standard on the overall risk management framework for the Islamic financial community that takes into account this unique requirement of Islamic banking.

While risk mitigation is desirable in Islamic finance, further improvements need to be made to the existing risk management framework. New hedging products which are scarce in the market need to be developed in the quest to seek for compatible risk mitigating products. In accordance with the principles Islamic the Shariah has allowed the Ummah to undertake juristic reasoning based on contemporary analysis and logical inference. Indeed, the development of new hedging products is something that the Islamic financial community can look forward to. In conventional banking, these instruments are used to mitigate risk. Indeed the Islamic financial community will soon develop such products for this purpose.

Basel II has also been accompanied by re-examination of the legal and regulatory frameworks for Islamic banking, in particular of those parts related to the incidence and management of banking risks and the role played by capital. This re-examination seems to be driven by factors such as the wish to enhance international perceptions of such banks and the enhanced interest in the management of financial risk generated by Basel II.

Some Islamic bankers argue that because of the nature of their deposits, Islamic banks should normally be expected to have a minimum capital of about three per cent of their total assets (liabilities) against such liabilities. This as compared with the minimum eight per cent set by the Basle Accord on Capital Adequacy for banks in general. Others stress that even if deposits are off balance sheet, there is always a fiduciary risk.

Requirements addressing the particularity of Islamic banks' balance sheet structure were introduced under Basel II. As a result of the particular nature of their activities, the risks borne by Islamic banking institutions differ to a greater or lesser extent from those outlined in Basel II. Serious attempts are being made by the Accounting and Auditing Organization for Islamic Financial Institutions (AAOIFI) and the Islamic Financial Services Board (IFSB) to develop a better capital adequacy framework that addresses the risk profile of Islamic banks.

Many steps have in the recent past been taken to devise an appropriate framework for the capital regulation of Islamic banks. The Accounting and Auditing Organization for Islamic Financial Institutions (AAOIFI) released a statement on the purpose and calculation of the capital adequacy ratio for Islamic banks in 1999, although the concept seems to need continual review. 


\section{Text in Al-Quran}

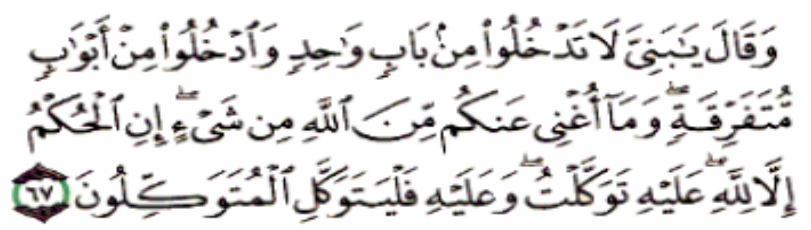

"O my children, do not enter the capital of Egypt by one gate but go into it by different gates. However, know it well that I cannot ward off you Allah's will for none other than He has nay authority whatsoever. In Him I have put my trust and all who want to rely upon anyone should put their trust in Him alone."

(Surah Yusuf: Verse 67)

\section{> Hadith from Prophet Muhammad s.a.w}

Prophet (peace be upon him) once asked a Bedouin who had left his camel untied, "Why do you not tie your camel?" The Bedouin answered, "I put my trust in God." The Prophet PBUH then said, "tie up your camel first then put your trust in God."

\section{Islamic Banking Business Activities}

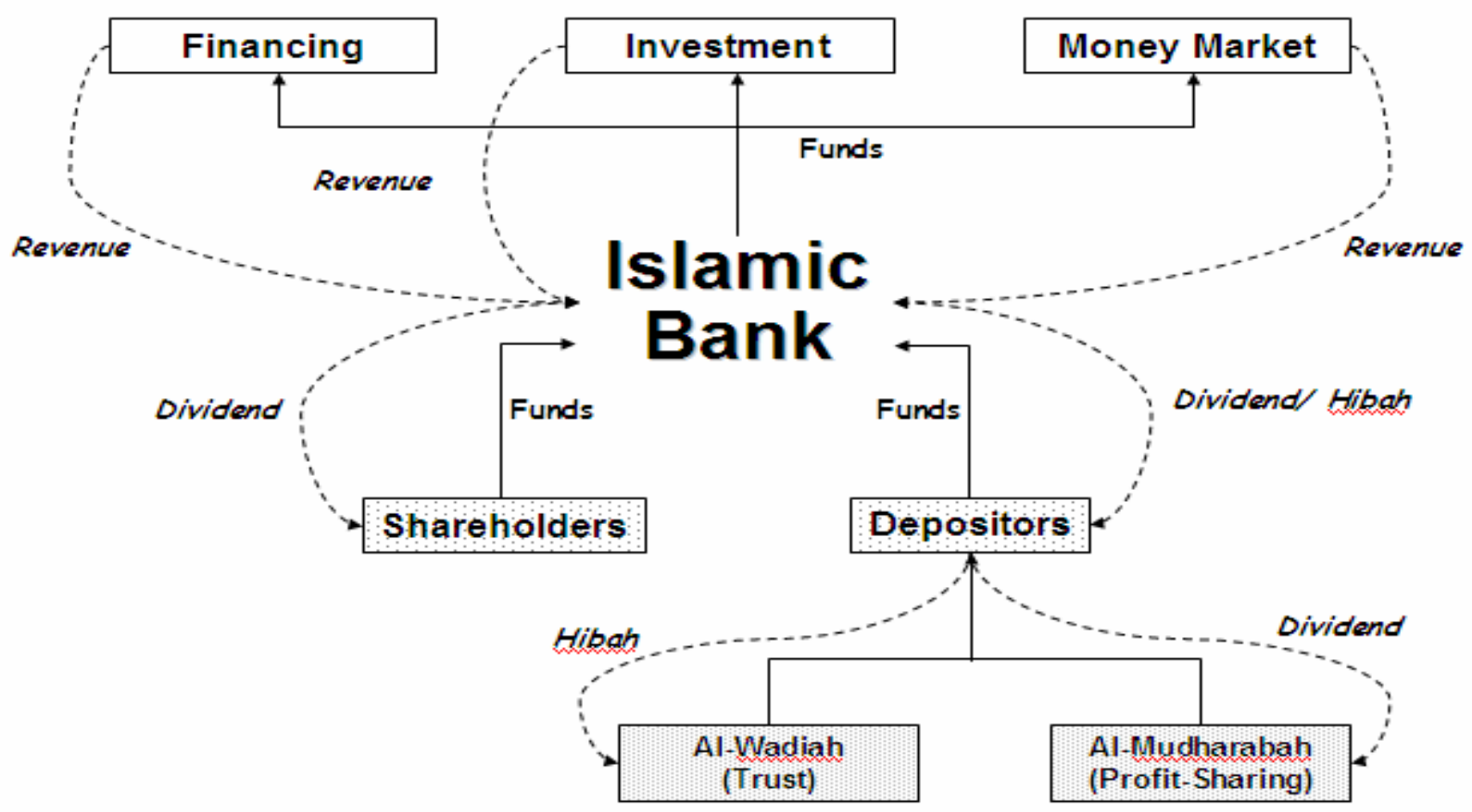

\section{Conclusion}

This paper examines the critical nature of risks in the general banking operation and how they affect the Islamic banking system in particular. It proves how risks in the Islamic banking industry are taken with utmost seriousness, how they are systematically assessed and effectively managed. The apparent insulation of the industry from the globalfinancial meltdown of 2008 is largely due to its unique risk-management frameworks which require further reinforcement to face future banking challenges. As the Islamic bank is more than forty years old, efforts need to be intensified professionally to further enhance its competitiveness to occupy larger portion in the global financial market. 


\section{References}

Ilias, S. E. B. (2012). Risk Management in Islamic Banking. DOI: 10.7763/IPED. V55, 32, 159-162.

Hennie van Greuning and Zamir Iqbal, H. (2007). Risk Analysis for Islamic Banks. Washigtion D.C: THE WORLD BANK.

Iqbal, H. V. (2008). Risk Analysis for Islamic banks . Washington D.C: The world bank . Jeroen P.M.M. Thijs, C.

R. .risk management in Islamic banking. bank Islam Malaysia

Berhad.

Sarieddine,R.T.(2007). Challenges in implementing capital adequacy - guidelines to islamic banks. Buirut : palgrave macmillan Ltd.Vol. 9,1 46-59 Journal of banking regulation.

V. Sundararajan.(2003). Risk Measurement and Disclosure in Islamic Finance and the Implications of Profit Sharing Investment Accounts.Washington, DC : Centennial Group Holdings.

\section{Copyrights}

Copyright for this article is retained by the author(s), with first publication rights granted to the journal.

This is an open-access article distributed under the terms and conditions of the Creative Commons Attribution license (http://creativecommons.org/licenses/by/4.0/). 